\title{
Does Religiosity Matter in Switching from Conventional to Islamic Insurance?
}

\author{
Evi Novitasaria, Christian Haposan Pangaribuan ${ }^{b}$ \\ ${ }^{\text {ab }}$ Sampoerna University, Jakarta, Indonesia \\ a evi.novitasari@my.sampoernauniversity.ac.id \\ ${ }^{\mathrm{b}}$ christian.pangaribuan@ sampoernauniversity.ac.id
}

\begin{abstract}
Objective - Despite the fact that Islamic insurance has grown significantly in Muslim countries; the number of market users was still very low compared to its market potential in Indonesia. The purpose of this research is to understand the factors that influence consumers to switch from conventional insurance to Islamic insurance.

Methodology - The influential factors being studied in this quantitative research are religiosity and product awareness and employs Qualtrics online survey that was administered to 200 Muslim customers of major life insurance over a period of 3 months (from June until August 2018). The group of population being the object in this study is Muslims who are non-participants of Islamic insurance, the current customers of conventional insurance who has monthly fix income and located in the city of Jakarta and its surroundings.

Findings - The results reveal religiosity to have a significant influence on switching attitudes and switching behavior. However, the other tests for the relationship between product awareness and switching attitudes as well as between product awareness and behavioral intention were not supported.

Novelty - Although past studies have investigated religiosity and product awareness in the context of switching from conventional to Islamic insurance, none have examined this issue in Indonesia. The paper concludes with the practical implications of the research.
\end{abstract}

Keywords: Religiosity; Insurance; Product Awareness; Switching Behavior

JEL Classification: D80, G22, Z12

Article info: Received 4 March 2021; Revised 6 April 2021; Accepted 4 May 2021

Article Correspondence: christian.pangaribuan@sampoernauniversity.ac.id

Recommended Citation: Novitasari, E. \& Pangaribuan, C. H. (2021). Does Religiosity Matter in Switching from

Conventional to Islamic Insurance? Journal of Multidisciplinary Issues, 1(1), 8-21.

\section{INTRODUCTION}

The market for Islamic insurance is gaining popularity and is driven by strong market growth of middle class economy. This particular insurance product has recorded a growth rate of 18\% over the 2007-2012 period worldwide, while its growth in ASEAN countries has been even higher, reaching $22 \%$. Islamic insurance contribution had reached US \$18.3 billion by June 2013 and is projected to exceed the US \$20 billion mark by 2017 (Ernst \& Young, 2015). As practiced by conventional companies, insurance is not permitted (haram) under the Sharia (Islamic law) (Todorof, 2018; Kamil \& Mat Nor, 2014) All that is permitted is joint insurance, where participants are the owners of funds. If a member or participant experiences a disaster, he/she will receive financial benefits from the fund to help alleviate loss or damage. The amount is taken from the general collection funds made with contributions from each participating member (Wahab et al., 2007). 
The fact that Indonesia is the country that has the largest Muslim population in the world does not mean that the country strongly influences the demand of Islamic insurance. Supposedly, this large number of Muslims in Indonesia will influence the way of people doing business, especially for the business targeting fellow Muslims. Reflecting the less desirable data, the market shares of Islamic insurance is merely 4.94\% as of August 2017 (Otoritas Jasa Keuangan, 2017). Unexpected, however, as this phenomenon of Islamic insurance performance has showed a remarkable growth from time to time with average operators' growth rate reaching 20\% annually (Lim et al., 2010). Furthermore, Indonesia's Otoritas Jasa Keuangan (Financial Services Authority) also mentioned that although the Islamic insurance premium always had a trending increase (about 5 to 25\%) from 2012 to 2016, the figure is still significantly lower than conventional insurance. In 2016, premium paid of Islamic insurance only amounted to 12,028 billion rupiahs (about US $\$ 850$ million); whilst premium of conventional insurance is 326,687 billion rupiahs or equivalent to US $\$ 23$ billion (Sidharta et al., 2017). It is argued that this condition has been influenced by several factors. First, Muslims are mostly unfamiliar with the product (Husin \& Rahman, 2016). Second, the concept of sharia still debatable to a certain extent (Suhardih, 2018). To overcome this, there are many parties taking roles in the development of it, e.g. Majelis Ulama Indonesia, as the official Islamic Indonesian organization that issues the fatwa despite poor responses from the society (Sidharta et al., 2017). Although the growth was promising, the level of participation of the Indonesian people in buying the insurance product was relatively low. This is not proportional to the Muslim population of Indonesia, which reached 237,641,326, accounting for 87 per cent of the entire population of the country (Badan Pusat Statistik, 2012). This fact shows that the potential of Islamic insurance market is still very large. Hence, the factors that influence the business development of this kind of insurance in Indonesia need to be investigated.

Previous studies showed that the development of Islamic insurance in Indonesia was still far behind Malaysia, where the population and percentage of Muslims are not as big as in Indonesia (Husin \& Rahman, 2016, Nasser \& Muhammed, 2013). Based on Ismanto's (2018) study on public literacy on Islamic banks in Central Java, Indonesia, it was found that there is no association between general knowledge and interest to become a customer of Islamic banks. Similarly, Choi et al. (2013) also conducted a research on how religious affiliation and religiosity affect consumer switching behaviors in Korea and U.S. The findings concluded that religiosity influences consumer switching behaviors, while religious affiliation does not. In a recent study conducted by Jamil \& Akhter (2016) to explore the impact of sharia perceptions on switching intentions among Islamic and life insurance customers, they found that the relationship was positive, but the mediating factor of customer satisfaction was not significant to the connection. Hence, it is important for an Islamic bank management to understand how Muslim customers perceive religiosity and the knowledge of Islamic insurance that convey different values to increase attitude towards switching from conventional insurance, which in turn can also create positive behavioral intentions because the customers are comfortable enough to have a positive action towards switching to it.

The research questions of this study are (1) Does religiosity have an influence on conventional insurance customer's attitude to switch to Islamic insurance? (2) Does product awareness have an influence on conventional insurance customer's attitude to switch to Islamic insurance? (3) Does religiosity have an influence on conventional insurance customer's behavior to switch to Islamic insurance? (4) Does product awareness have a significant positive influence on conventional insurance customer's behavior to switch to Islamic insurance?

\section{LITERATURE REVIEW}

\section{Islamic Insurance}

Jamil and Akhter (2016) argue that Islamic insurance brings more benefits compared to conventional insurance due to its concept of where it provides their participants (customers) an opportunity to adhere to religious obligation in insurance matters, while at the same time presents itself as a form of mutual help 
(taawum) as in furthering virtue by partnering to help others who are in need or hardship. Furthermore, it is beneficial for Muslim participants in terms of religiosity because the participants cooperate among themselves for their common good; every participant pays his or her subscription in order to assist those of them who need assistance; it falls under a donation contract, which is intended to divide losses and spread liability according to the community pooling system; the element of uncertainty is eliminated insofar as subscription and compensation are concerned; and it does not aim to derive advantage at the cost of other individuals (Wahab et al., 2007).

\section{Religiosity}

Religion is a complex human phenomenon, and has produced a wide variety amount of grounds to measure, including attitudes, beliefs, and values (Hill \& Hood, 1999). Meanwhile, religiosity echoes aspects of a person's religious beliefs and activities in life intrinsically (implying personal motives in religion) as well as extrinsically (reflecting valuable aspects of religion) (Agorastos et al., 2014). In addition, Khraim (2010) provided a study that seeks to assess the most suitable combination of dimensions that gives the best results in measuring Islamic religiosity. Seven factors were extracted by factor analysis form the four dimensions. The findings of the study indicated that the combination of three dimensions (current Islamic issues, religious education, and sensitive products) produce the best results among other dimensions. Farouk et al. (2018) studied the moderating role of religiosity in shaping the intention to comply with the zakat on employment income. They argued that religiosity influenced subjective norm and behavioral intention indirectly, but not on the relationship between attitude and behavioral intention. Haji-Othman et al. (2018) measured whether Islamic religiosity moderates the relationship between attitude, subjective norms, perceived behavioral control and moral obligation, and intention to comply with income zakat payment. This study found that Islamic religiosity played a significant role in moderating the relationship between perceived behavioral control and intention. This finding recommended that the state should consider planning, strategizing and implementing an effective intervention by stressing the importance of complying with zakat payment which is a religious obligation to Muslims. Al-hajla et al. (2019) have also found a strong support for the link between religious beliefs, brand personality, and new religion-compliant product adoption in Islamic markets. The findings of the study shed light on the tendency of religious consumers to behave in accordance with a society or group that follows the same beliefs, and that these consumers' behavior and lifestyle are influenced by similar religious groups and social relationships.

\section{Product Awareness}

Recognition and recall are made when consumers are making purchase decisions and evaluating product usage experience or product quality (Zhang, 2020). The customers' awareness is the result of a firm's strategies in marketing, for example through advertising expenditures, then the customers will shape their decisions based on it. To get to know a specific product or service, it is known that consumers go through several stages including awareness, consideration and choice in their shopping process before making a purchase decision towards the existed choices. Most of demand side models assume that consumers are actually aware of and consider all available alternatives (Honka et al., 2014). Then, the customers make the decision by maximizing their utility by choosing among them (Berry, 1994). To takaful, similarly, the success of insurance industry depends on the factors like consumer awareness, service, and economic security (Khare et al., 2012). According to Kaur and Bhatia (2018), lack of knowledge and awareness about the basics and technicality of the products and services that customers are dealing with can lead to a deficiency in customer-motivated reasons to possess products and services. Thus, the insurance providers need to educate their potential customer to increase their awareness and knowledge regarding the product of takaful. In order to avoid resistance, insurance providers need to ensure that the consumers are certain about the product by providing information about it (Labrecque et al., 2016). 


\section{Attitude towards Switching}

Attitudes towards switching are related to the assumed motives for switching (or not switching) that is loyalty to the incumbent, information search costs to compare products, and expected economic benefits (Gamble et al., 2009). Attitude towards switching was found to be the most important determinant of a customer's switching intention, which in turn influences significantly the switching behavior of customers. Attitude toward switching was found to be significantly influenced by subjective norms, and switching intention was influenced by satisfaction and service quality (Nimako, 2012). The reasons for switching referred to here have been related to the particular kinds of switching described as total, partial, or internal according to a unique pattern of customer preferences, with behavior as the reference point. This pattern indicates the industry-specific configuration of reasons for customer sensitiveness to switching (Edvardsson et al., 2002). The customers' own expressions of their reasons for switching are labeled switching determinants and are included in the switching configuration. For example, price is commonly expressed as a switching determinant and frequently combined with an influential trigger (Roos et al., 2004). While in this research, the switching determinants that will be tested are religiosity and product awareness of Islamic insurance.

\section{Switching Behavior}

Switching between brands is a consumer behavior phenomenon where consumers shift their loyalty from one brand to another (Suryawardani \& Wulandari, 2020). Existing consumer switching behavior literature has addressed the factors, the so-called triggers that lead consumers to switch to a different brand, product, or service provider (Choi et al., 2013). In today's dynamic marketplace, the business organizations are increasingly being customer-oriented because they are realizing the importance of keeping customers in a long-term relationship (Nimako, 2012). Thus, it is very important to explore and examine the factors that can cause customers to switch service firms. There are some factors that affect customer switching behavior from the perspectives of customers' psychology and society; including the emotional intelligence of customers, personality traits and relationship involvement (Keaveney, 1995). Customer switching behavior can be particularly damaging for subscription or membership-based service firms where customers commit to ongoing relationships and services are continuously provided.

\section{Conceptual Framework and Hypotheses Development}

The conceptual model detailing the hypothesized effects of religiosity and product awareness on switching attitude and switching behavior is detailed in Figure 1. Based on this conceptual model, the following hypotheses are developed and tested.

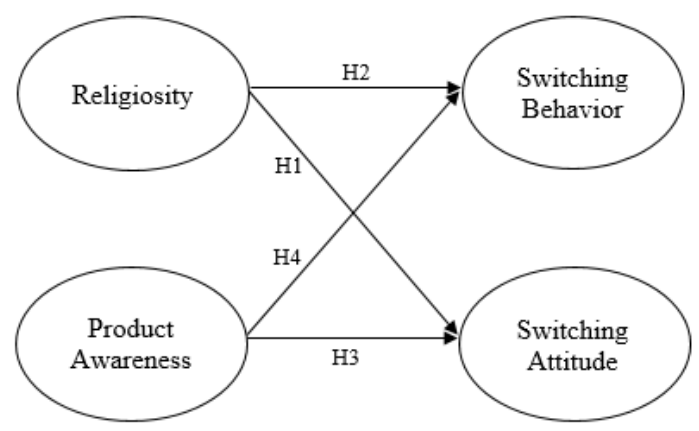

Figure 1. Research Model

Based on Graafland's (2015) study, it was proposed that religiosity would have significant positive influence on behavior. The findings suggested that attitude could foster a demand for products offered. Haji-Othman et al.'s (2018) study examined the determinants of compliance behavior with Islamic 
religiosity as a moderating variable. The result showed that religiosity was found to play a significant role in moderating the relationship between perceived behavioral control and intention. Similarly, Farouk et al. (2018) found that the moderating role of Islamic religiosity was significant between subjective norms and behavioral intention. Thus, we can hypothesize:

Hypothesis 1 (H1): The association of switching attitude is influenced by religiosity.

Hypothesis 2 (H2): The association of switching behavior is influenced by religiosity.

In education industry, environmental knowledge would help people develop positive attitudes (Erten et al., 2003). Providing product information to consumers is likely to make it easier for consumers to make informed purchase decisions (Makanyeza \& Du Toit, 2015). Availability of information is important to the success of channel-switching and has important implications for business-making decisions (Pookulangara et al., 2011). Hence, based on the above discussion, this study hypothesizes that:

Hypothesis 3 (H3): The association of switching attitude is influenced by product awareness.

Hypothesis 4 (H4): The association of switching behavior is influenced by product awareness.

Table 1. Dimensions and Indicators of the Variables

\begin{tabular}{|c|c|}
\hline Dimensions & Measurement Indicators \\
\hline \multirow[t]{2}{*}{ Spiritual commitment } & My beliefs are my whole approach to life (REL1) \\
\hline & Carrying religion over into all other dealings in life (REL2) \\
\hline Importance of religious values & Important to spend time in private religious thought (REL3) \\
\hline \multirow[t]{2}{*}{ Belief in one's religion } & My beliefs are very important to me (REL4) \\
\hline & My faith sometimes restricts my actions (REL5) \\
\hline \multirow[t]{3}{*}{ Product information } & The awareness of Islamic insurance (PA1) \\
\hline & The attention paid to Islamic insurance (PA2) \\
\hline & The supports for Islamic insurance (PA3) \\
\hline \multirow[t]{2}{*}{ Product knowledge } & The knowledge towards Islamic insurance (PA4) \\
\hline & The influence of benefit using Islamic insurance (PA5) \\
\hline Difference & The degree of agreeableness in switching into Islamic insurance (SWA1) \\
\hline \multirow[t]{2}{*}{ Benefits } & The degree of usefulness in switching into Islamic insurance (SWA2) \\
\hline & The degree of benefits in switching into Islamic insurance (SWA3) \\
\hline Contact & The degree of liking in switching into Islamic insurance (SWA4) \\
\hline Involvement & The degree of possibility in switching into Islamic insurance (SWA5) \\
\hline Price & Influence of pricing (CSB1) \\
\hline Customer Commitment & Influence of convenience (CSB2) \\
\hline Customer Convenience & Influence of core service value (CSB3) \\
\hline \multirow[t]{2}{*}{ Responses to Service Failure } & Influence of service encounter value (CSB4) \\
\hline & Influence of response to service failure (CSB5) \\
\hline Effective Advertising & Influence of competition (CSB6) \\
\hline \multirow[t]{2}{*}{ Involuntary Switching } & Influence of ethical problem (CSB7) \\
\hline & Influence of involuntary switching (CSB8) \\
\hline
\end{tabular}

\section{METHODOLOGY}

The method used in this research was non-probability purposive sampling. The questionnaires were distributed during weekdays over a period from June to August 2018. The data were collected from customers of major life insurance. The group of population being the object in this study is Muslims who are non-participants of Islamic insurance, the current customers of conventional insurance who has monthly 
fix income and located in the city of Jakarta and its surrounding suburban areas of Bogor, Depok, Tangerang and Bekasi.

In this study, the determination of the number of samples needed was based on Hair et al.'s (2013) argument that to get representative samples from a population, the number of indicators had to be multiplied by $5-10$. The number of respondents would depend on the number of indicators of the variables, and this study employed 23 variable indicators (see Table 1). Of the 215 distributed using Google Form, only 200 responses were valid, resulting in a response rate of $93.02 \%$.

This study uses primary data collection where the questionnaires are created and distributed using an online survey platform named Qualtrics. The respondents were expected to fill out the questions provided on the questionnaire based on the guideline provided by the researchers. This kind of data gathering method was more efficient, reduce cost, paperless and faster.

The questionnaire was constructed by using three different scales: Likert scale, Semantic Differential Scale and Visual Analogue Scale. Likert Scale is the scaling method where are presented with one or more attitudinal statements and asked to score each statement on a multi-point scale (Mathers et al., 2009). In this research, the Likert Scale was used to measure the variable of Religiosity, Product Awareness, and Customer Switching Behavior. Furthermore, in the questionnaire, a 4-degree Likert Scale was employed with the following scale measurements: Strongly Disagree is worth 1 point, Disagree is worth 2 points, Agree is worth 3 points, and Strongly Agree is worth 4 points.

Table 2. Demographic Profiles

\begin{tabular}{|c|c|c|c|}
\hline Variable & Description & Frequency & Percent \\
\hline \multirow[t]{2}{*}{ Gender } & Male & 91 & 45.50 \\
\hline & Female & 109 & 54.50 \\
\hline \multirow[t]{5}{*}{ Age } & Less than 21 & 5 & 2.50 \\
\hline & $21-30$ & 146 & 73.00 \\
\hline & $31-40$ & 33 & 16.50 \\
\hline & $41-50$ & 14 & 7.00 \\
\hline & More than 50 & 2 & 1.00 \\
\hline Monthly & $<$ IDR 2,500,000 & 26 & 13.00 \\
\hline \multirow[t]{4}{*}{ Income } & $2,500,000-5,000,000$ & 53 & 26.50 \\
\hline & $5,000,001-7,500,000$ & 58 & 29.00 \\
\hline & $7,500,001-10,000,000$ & 23 & 11.50 \\
\hline & $>$ IDR $10,000,000$ & 40 & 20.00 \\
\hline Town of & Jakarta & 129 & 64.50 \\
\hline \multirow[t]{4}{*}{ Residency } & Bogor & 10 & 5.00 \\
\hline & Depok & 22 & 11.00 \\
\hline & Tangerang & 25 & 12.50 \\
\hline & Bekasi & 14 & 7.00 \\
\hline Minimum & High School & 24 & 12.00 \\
\hline Education & Associate Degree & 25 & 12.50 \\
\hline \multirow[t]{3}{*}{ Level } & Undergraduate & 120 & 60.00 \\
\hline & Masters & 28 & 14.00 \\
\hline & Doctoral & 3 & 1.50 \\
\hline
\end{tabular}

\section{RESULTS AND DISCUSSION}

\section{Demographic Analysis}

All respondents were adult male and female Muslim customers of conventional insurance consisted of 109 female (54.5 percent) and 91 male (45.5 percent). For the age group, $73.0 \%$ of the respondents are 
within the age group between 21-30 years old. Most of the respondents (29.0 percent) had monthly income range between IDR 5,000,001 and IDR 7,500,000 (equal to between US \$354 and US \$531). The major chunk of the respondents (64.5 percent) had Jakarta as their town of residence. For the level of education, most of the respondents have educational background in bachelor, masters, and associate which were $60 \%$, $14 \%$ and $12.5 \%$ respectively compared to the post-graduate and high school. The results of respondent's demographic, socio-economic and geographic variables were summarized in Table 2.

The researchers assessed the validity and reliability of the variables through a pre-test by getting inquiries from 30 respondents. The result can be seen in Table 3. The questionnaire consisted of 4 variables. In total, there are 23 items on the questionnaire. In order to check both validity and reliability, IBM SPSS Statistics version 24 was used. The minimum value of KMO and Anti-image correlation for validity test was 0.5 (Field, 2005). For each instrument, the Cronbach's Alpha of Religiosity is 0.898, Product Awareness 0.864, Switching Attitude 0.881, and Switching Behavior 0.833. The recommended cut off point for Cronbach's alpha reliable test is 0.7 (Hair et al., 2013). All the reliability scores are above recommended cut-off point, therefore all the remaining instruments are valid and reliable.

Table 3. Validity and Reliability Tests of the Variables

\begin{tabular}{cccccc}
\hline Factor & Item & KMO & Coefficients & Alpha & Note \\
\hline Religiosity & REL1 & & 0.844 & & Valid \\
& REL2 & & 0.861 & Valid \\
& REL3 & 0.853 & 0.861 & 0.898 & Valid \\
& REL4 & & 0.842 & Valid \\
& REL5 & 0.857 & Valid \\
\hline Product & PA1 & & 0.526 & Valid \\
Awareness & PA2 & & 0.761 & Valid \\
& PA3 & 0.707 & 0.708 & 0.864 & Valid \\
& PA4 & & 0.684 & & Valid \\
& PA5 & & 0.711 & Valid \\
\hline Switching & SWA1 & & 0.873 & Valid \\
Attitude & SWA2 & & 0.76 & Valid \\
& SWA3 & 0.751 & 0.639 & 0.881 & Valid \\
& SWA4 & & 0.786 & & Valid \\
& SWA5 & & 0.698 & Valid \\
\hline Switching & CSB1 & & 0.626 & Valid \\
Behavior & CSB2 & & 0.816 & & Valid \\
& CSB3 & & 0.835 & & Valid \\
& CSB4 & 0.750 & 0.763 & & Valid \\
& CSB5 & & 0.716 & & Valid \\
& CSB6 & CSB7 & & 0.655 & Valid \\
& CSB8 & & 0.782 & Valid \\
& & 0.725 & & Valid \\
\hline & & &
\end{tabular}

\section{Religiosity towards Switching Attitude}

According to Table 7, the $\rho$-value of REL is lower than $\alpha(0.000<0.05)$. Referring to the rule of thumb, when the $\rho$-value is less than the $\alpha$, the variable tested is significant. Furthermore, the result of t-test in REL is showing the value of -4.356 which is less than the t-table value of 1.973 . Overall, the variable is significant and $\mathrm{H} 0$ should be rejected while $\mathrm{H} 1$ should be accepted. It is also indicating that the dependent variable of Customer Switching Attitude (SWA) is influenced by the independent variable of Religiosity (REL). In addition, based on the analysis of Unstandardized Coefficients (B), the relation between the dependent and the independent variable in this model is negatively related. It is proved by the increase of 1 
score in Religiosity (REL), the Customer Switching Attitudes (SWA) value will decrease by 0.393. Similar to what Souiden \& Rani's (2015) study, it was found that religiosity did have an impact towards attitude. The more a person fears punishment from God and believes in Islamic laws, the more they will develop a favorable attitude towards Islamic products, e.g. banks.

The multicollinearity was measured by variance inflation factors (VIF) and tolerance to find out whether there was a high correlation between the independent variables. The relationship of the dependent variable was biased if there was a strong correlation between the independent variables. If VIF value is exceeding 4.0 , or by tolerance less than 0.2 , then there is a problem. The rule of thumb for multicollinearity test is considering both result of tolerance and VIF where if the tolerance above 0.1 and VIF is below 10, it means that the variable is free of multicollinearity. There was no significant collinearity detected and the results of both models 1 and 2 are represented in Table 4.

Table 4. Multicollinearity Tests

\begin{tabular}{lcc}
\hline \multicolumn{1}{c}{ Model 1 } & \multicolumn{2}{c}{ Collinearity Statistics } \\
& Tolerance & VIF \\
\hline Religiosity & 0.587 & 1.704 \\
Product Awareness & 0.587 & 1.704 \\
a. Dependent Variable: Switching Attitude & \multicolumn{2}{c}{ Collinearity Statistics } \\
\multicolumn{1}{c}{ Model 2 } & Tolerance & VIF \\
\hline Religiosity & 0.587 & 1.704 \\
Product Awareness & 0.587 & 1.704 \\
a. Dependent Variable: Switching Behavior & & \\
\hline
\end{tabular}

The R values for both Model 1 (0.451) and Model 2 (0.322) in Table 5 indicate the strength of the overall linear relationship. The values of the coefficient of determination are higher than 0.1 , meaning that the linear relationships are strong. To measure the proportion of variation in dependent variable towards all independent variables, the R square was used as the measurement, which is 0.203 and 0.104 for Model 1 and Model 2, respectively. For Model 1, it means that $20.3 \%$ of the dependent variable (Switching Attitude) can be described through the 2 independent variables (Religiosity and Product Awareness). The rest of $79.7 \%$ was influenced by other factors excluded from the model. For the second model, $10.4 \%$ of Switching Behavior can be described through Religiosity and Product Awareness.

As seen in Table 6, the F-test result in Model 1 shows that the significant value is 0.000 that is considered less than alpha $(<0.05)$ which means that Model 1 is significant. The F-statistic result also shows higher number than F-table $(23.702>3.89)$ which describes that $\mathrm{HO}$ is rejected. For Model 2, the F-stat value is also higher than the F-table $(10.795>3.89)$. In conclusion, the two models are significant.

\section{Religiosity towards Switching Behavior}

In Table 8, the $\rho$-value of Religiosity (REL) is 0.000 and it is lower than the $\alpha$ used; 0.05. Again, the variable tested is significant. Furthermore, the result of t-test in REL is showing the value of -4.154 which is less than the t-table value of -1.973 . Thus, the variable is significant and $\mathrm{H} 0$ should be rejected while $\mathrm{H} 1$ should be accepted. It is also indicating that the dependent variable of Customer Switching Behaviour (CSB) is influenced by the independent variable of Religiosity (REL). In addition, based on the analysis of Unstandardized Coefficients (B), the relation between the dependent and the independent variable in this model is negatively related. It is proved by the increase of 1 score in Religiosity (REL), the Customer Switching Behavior (CSB) value will decrease by 0.287. The result is consistent with Choi et al.'s (2013) investigation. Their findings suggest that religiosity can be a trigger that influences consumer switching behaviors. 
Table 5. Multi Regression Test

\begin{tabular}{ccccc}
\hline Model & $\mathbf{R}$ & $\mathbf{R}^{\mathbf{2}}$ & Adjusted $\mathbf{R}^{\mathbf{2}}$ & $\begin{array}{c}\text { Std. Error of } \\
\text { the Estimate }\end{array}$ \\
\hline 1 & 0.451 & 0.203 & 0.195 & 0.63553 \\
2 & 0.322 & 0.104 & 0.094 & 0.48601 \\
\hline
\end{tabular}

\section{Product Awareness towards Switching Attitude}

According to Table 7, the $\rho$-value of Product Awareness (PA) is 0.050 and it is equal to the $\alpha$ used; 0.05 . Referring to the rule of thumb, when the $\rho$-value is equal to the $\alpha$, the variable tested is significant. Furthermore, the result of t-test in PA is showing the value of -1.286 which is higher than the t-table value of -1.973. Overall, the variable is not significant and H0 should be accepted while H1 should be rejected. It is also indicating that the dependent variable of Customer Switching Attitudes (SWA) is not influenced by the independent variable of Product Awareness (PA). In addition, based on the analysis of Unstandardized Coefficients (B), the relation between the dependent and the independent variable in this model is positively related. It is proved by the increase of 1 score in Product Awareness (PA), the Customer Switching Attitudes (SWA) value will increase by 0.128. The result of the relation between customer awareness and customer switching attitudes in this model is relevant with previous research by Bibi et al (2015) who found that awareness did not impact customers to switch to a different product.

Table 6. F-test Result

\begin{tabular}{clccccc}
\hline \multirow{2}{*}{ Model } & & $\begin{array}{c}\text { Sum of } \\
\text { Squares }\end{array}$ & df & $\begin{array}{c}\text { Mean } \\
\text { Square }\end{array}$ & F & Sig. \\
\hline \multirow{2}{*}{1} & Regression & 19.146 & 2 & 9.573 & 23.702 & 0.000 \\
& Residual & 75.126 & 198 & 0.404 & & \\
& Total & 94.272 & 200 & & & \\
\hline \multirow{2}{*}{2} & Regression & 5.100 & 2 & 2.550 & 10.795 & 0.000 \\
& Residual & 43.935 & 198 & 0.236 & & \\
\hline
\end{tabular}

Table 7. Beta Coefficients for Model 1 (towards ATT)

\begin{tabular}{clccccc}
\hline & \multirow{2}{*}{ Model } & \multicolumn{2}{c}{ Unstandardized Coefficients } & Standardized Coef. & \multirow{2}{*}{ t } & Sig. \\
\cline { 3 - 5 } & & B & Std. Error & Beta & & \\
\hline \multirow{2}{*}{1} & (Constant) & 4.265 & 0.188 & & 22.628 & 0.000 \\
& REL & -0.393 & 0.090 & -0.372 & -4.356 & 0.000 \\
& PA & -0.128 & 0.099 & -0.110 & -1.286 & 0.050 \\
\hline
\end{tabular}

\section{Product Awareness towards Switching Behavior}

In Table 8, the $\rho$-value of Product Awareness (PA) is 0.110 and it is greater than the $\alpha$ of 0.05 . Thus, the variable tested is not significant. Furthermore, the result of t-test in PA is showing the value of 1.074 which is less than the t-table value of 1.973. Therefore, the variable is not significant and H0 should be accepted 
while $\mathrm{H} 1$ should be rejected. It is also indicating that the dependent variable of Customer Switching Behaviour (CSB) is not influenced by the independent variable of Product Awareness (PA). In addition, based on the analysis of Unstandardized Coefficients (B), the relation between the dependent and the independent variable in this model is positively related. It is proved by the increase of 1 score in Product Awareness (PA), the Customer Switching Behavior (CSB) value will increase by 0.082 . This finding corroborated Ustaouglu's (2014) study that as education level increases, the conventional insurance companies are preferred and that mostly (75\%) religious people prefer an Islamic insurance. However, participants have little information on Islamic insurance because such services were considered relatively new. Clemes et al. (2010) found negative relationship between effective advertising competition and switching behavior in Chinese retail banking industry. Advertising affects customers' behavior because it provides information guide to customer and facilitate their purchasing decisions.

Table 8. Beta Coefficients for Model 2 (towards BEH)

\begin{tabular}{|c|c|c|c|c|c|c|}
\hline & \multirow{2}{*}{ Model } & \multicolumn{2}{|c|}{ Unstandardized Coefficients } & \multirow{2}{*}{$\begin{array}{c}\text { Standardized Coef. } \\
\text { Beta }\end{array}$} & \multirow{2}{*}{$\mathbf{t}$} & \multirow{2}{*}{ Sig. } \\
\hline & & B & Std. Error & & & \\
\hline \multirow[t]{3}{*}{2} & (Constant) & 2.760 & 0.144 & & 19.151 & 0.000 \\
\hline & REL & -0.287 & 0.069 & -0.376 & -4.154 & 0.000 \\
\hline & $\mathrm{PA}$ & 0.082 & 0.076 & 0.097 & 1.074 & 0.110 \\
\hline
\end{tabular}

\section{CONCLUSION}

This current study has sought to examine possible effects in behavioral theory in predicting switching from one type of insurance to another. An empirical investigation examined this issue with data from Muslim customers of different conventional insurance companies. The research presented in this paper was designed to explore the roles of religiosity and product awareness in determining customers' attitude and intentions in terms of switching from a conventional insurance to an Islamic insurance. The main conclusion of this study is that religiosity is an important antecedent of switching attitude and switching behavior. However, its relationship with the latter variable is negative, more complex than originally thought. From the proposed model, one can conclude that the relationships between product awareness and both switching attitude and switching behavior were not statistically significant. The results of this study have both theoretical and managerial implications, which are elaborated upon in greater detail in the following sections.

\section{Theoretical Implications}

From the theoretical perspective, one of the most important contributions of this study is its demonstration of a direct link between religiosity and attitude. One point that emerges from this study is that religiosity predicted insurance-switching attitude. Providing support to the theory, religious belief is the antecedent to insurance-switching attitude. This result is in line with Fam et al.'s (2004) findings which suggest that religious belief would have an influence towards the attitude towards advertising of particular controversial products and services. Furthermore, the other contribution of this current research is that there is a positive relationship between religiosity and switching behavior. The present study confirms the opinion of Choi et al. (2013) specifying that religiosity can be a trigger that influences consumer switching behaviors. Although the direct relationship between product awareness and switching attitude was found to be insignificant in this study, the results still provide insights for future research into why this linkage is weak. Similarly, the direct link between product awareness and switching behavior was not significant. Therefore, future research can be to further understand how the dimensions of product awareness that 
interact and influence consumer switching behaviors could provide more in-depth insights into identifying and understanding the dimensions as "triggers" for consumer switching attitude and behaviors.

\section{Managerial Implications}

The result shows that Islamic teaching is very influential to the consumers' switching attitudes. It is shown that it is negatively related. The other finding in this research also shows that religiosity is not only influencing switching attitudes, but switching behavior as well. Again, those variables are negatively related. Religiosity enhances consumer-brand connection because religious consumers are more likely to incorporate brands into their self-concept, which thus increases their psychological attachment to their favorite brands (Qin \& Xu, 2016). Meanwhile, religiosity also enhances trustworthiness, transparency, and accountability, for they are integral operational life principles from God (Mylek \& Nel, 2010). As a consequence, when the other brand offers a switching incentive (e.g., a discount), thus providing a better option that being less expensive is more justifiable than one's favorite brand, religious belief will turn the consumers to switch to the competing brand (Qin \& Xu, 2016). Therefore, insurance providers are suggested not to employ religion or Islamic teaching to maintain their consumers' attitude and behavior, instead to maximize the other influential factors, e.g. convenience, the core service, the service encounter failures or provider's the response to service failure (Keaveney, 1995).

\section{Limitations and Future Research}

Since the convenience sampling method was used to collect the research data, the generalizability of the results is limited. To ensure external validity, a more comprehensive sample in a wider range of restaurants is needed in future research. To deepen understanding of the relationship between religiosity and consumer behavior, other factors such as demographic information, customer nationality, and different insurance types could also be incorporated in future.

\section{REFERENCES}

Agorastos, A., Huber, C. G., \& Demiralay, C. (2014). Influence of religious aspects and personal beliefs on psychological behavior: focus on anxiety disorders. Psychology Research and Behavior Management, 7, 93-101. https://dx.doi.org/10.2147\%2FPRBM.S43666

Al-hajla A. H., Nguyen, B., Melewar, T. C., Jayawardhena, C., Ghazali, E., \& Mutum, D. S. (2019). Understanding New Religion-Compliant Product Adoption (NRCPA) in Islamic Markets. Journal of Global Marketing, 1-15. https://doi.org/10.1080/08911762.2018.1559907

Badan Pusat Statistik (2012). Kewarganegaraan, Suku Bangsa, Agama, dan Bahasa Sehari-hari Penduduk Indonesia (Hasil Sensus Penduduk 2010). Jakarta: Badan Pusat Statistik.

Berry, S. T. (1994). Estimating Discrete-Choice Models of Product Differentiation. The RAND Journal of Economics, 25(2), 242-262. https://doi.org/10.2307/2555829

Choi, Y., Paulraj, A., \& Shin, J. (2013). Religion or Religiosity: Which Is the Culprit for Consumer Switching Behavior? Journal of International Consumer Marketing, 25(4), 262-280. http://dx.doi.org/10.1080/08961530.2013.803901

Clemes, M. D., Gan, C., \& Zhang, D. (2010). Customer switching behaviour in the Chinese retail banking industry. International Journal of Bank Marketing, 28(7), 519-546. https://doi.org/10.1108/02652321011085185

Edvardsson, B., Gustafsson, A., \& Roos, I. (2002). Comparing Switching Patterns in Competitive and NonCompetitive Markets-Customer Preferences and Behavior in Five Service Industries. 11th Annual American Marketing Association Frontiers in Services Conference, June 27-29, Maastricht, the Netherlands. 
Erten, S., Ozdemir, P., \& Güler, T. (2003). Determination of the pre-school teachers' levels of environmental awareness and the status of environmental education in these schools, Proceedings from the OMEP 2003 World Council and Conference, Turkey, 2(2003), 334-350.

Ernst \& Young (2015). Global Takaful Insight Report 2014: Market Updates. Ernst and Young.

Fam, K. S., Waller, D. S., \& Erdogan, B. Z. (2004). The influence of religion on attitudes towards the advertising of controversial products. European Journal of Marketing, 38(5/6), 537-555. http://dx.doi.org/10.1108/03090560410529204

Farouk, A. U., Idris, K. M., \& bin Saad, R. A. J. (2018). Moderating role of religiosity on Zakat compliance behavior in Nigeria. International Journal of Islamic and Middle Eastern Finance and Management, 11(3), 357-373. http://doi.org/10.1108/IMEFM-05-2017-0122

Gamble, A., Juliusson, E. A., \& Garling, T. (2009). Consumer attitudes towards switching supplier in three deregulated markets. The Journal of Socio-Economics, 38(2009), 814-819. https://doi.org/10.1016/j.socec.2009.05.002

Graafland, J. (2015). Religiosity, Attitude, and the Demand for Socially Responsible Products. Journal of Business Ethics, 144(1), 121-138. https://doi.org/10.1007/s10551-015-2796-9

Hair, J., Black, W., Babin, B., \& Anderson, R. (2013). Multivariate Data Analysis (7th Edition). Essex: Pearson Education Limited.

Haji-Othman, Y., Fisol, W. N. M., \& Yusuff, M. S. S. (2018). The Moderating Effect of Islamic Religiosity on Compliance Behavior of Income Zakat in Kedah, Malaysia. International Journal of Academic Research in Accounting, Finance and Management Sciences, 8(2), 281-286. http://dx.doi.org/10.6007/IJARAFMS/v8-i2/4382

Hill, P. C., \& Hood, R. W., Jr. (Eds.) (1999). Measures of Religiosity. Birmingham, AL: Religious Education Press.

Honka, E., Hortacsu, A., \& Vitorino, M. A. (2014). Advertising, Consumer Awareness and Choice: Evidence from the U.S. Banking Industry. The RAND Journal of Economics, 48(3), 1-44. https://doi.org/10.1111/1756-2171.12188

Husin, M. M., \& Rahman, A. A. (2016). Do Muslims Intend to Participate in Islamic Insurance? Analysis from Theory of Planned Behavior. Journal of Islamic Accounting and Business Research, 7(1), 42-58. http://dx.doi.org/10.1108/JIABR-03-2014-0012

Ismanto, K. (2018). Literasi Masyarakat dan Dampaknya terhadap Minat Menjadi Nasabah Bank Syariah. Human Falah, 5(1), 14-27. from http://jurnal.uinsu.ac.id/index.php/humanfalah/article/download/1318/1352

Jamil, H., \& Akhter, W. (2016). Investigating the impact of Shari'ah perception on customer switching intentions: A study of Takaful and conventional insurance. Cogent Business \& Management, 3(1), 1-11. http://dx.doi.org/10.1080/23311975.2016.1261525

Kamil, N. M. \& Mat Nor, N. B. (2014). Factors Influencing the Choice of Takaful Over Conventional Insurance: The Case of Malaysia. Journal of Islamic Finance, 3(2), 1-14. https://ssrn.com/abstract $=2542115$

Kaur \& Bhatia (2018). The Impact of Consumer Awareness on Buying Behavior of Green Products. International Journal of Scientific Research and Management, 6(4), 250-255. https://doi.org/10.18535/ijsrm/v6i4.em03

Keaveney, S. M. (1995). Customer switching behavior in service industries: An exploratory study. Journal of Marketing, 59(2), 71-82. https://doi.org/10.2307/1252074

Khare, A., Dixit, S., Chaudhary, R., Kochhar, P., \& Mishra, S. (2012). Customer behavior toward online insurance services in India. Journal of Database Marketing \& Customer Strategy Management, 19(2), 120-133. https://doi.org/10.1057/dbm.2012.14

Khraim, K. (2010). Measuring Religiosity in Consumer Research from Islamic Perspective. International Journal of Marketing Studies, 2(2), 166-179. https://doi.org/10.5539/IJMS.V2N2P166 
Labrecque, J. S., Wood, W., Neal, D. T., \& Harrington, N. (2016). Habit slips: when consumers unintentionally resist new products. Journal of the Academy of Marketing Science, 45(1), 119-133. https://doi.org/10.1007/s11747-016-0482-9

Lim, J., Idris, M. F., \& Carissa, Y. (2010). History, progress and future challenge of Islamic Insurance (Takaful) in Malaysia. Paper presented at the 2010 Oxford Business \& Economics Conference Program, Oxford, UK, 2010.

Makanyeza, C., \& Du Toit, F. (2015). Examining the measurement and dimensionality of the construct of consumer awareness in a developing and transition economy. SA Journal of Industrial Psychology/SA Tydskrif vir Bedryfsielkunde, 41(1), 1-9. https://doi.org/10.4102/sajip.v41i1.1250

Mathers, N., Fox, N., \& Hunn, A. (2009). Surveys and Questionnaires. The NIHR RDS for the East Midlands/Yorkshire \& the Humber, 1-48.

Mylek, I., \& Nel, P. (2010). Religion and relief: the role of religion in mobilizing civil society against global poverty. Kotuitui: New Zealand Journal of Social Sciences Online, 5(2), 81-97. https://doi.org/10.1080/1177083X.2010.519391

Nasser, S. A. S. A., \& Muhammed, D. D. J. (2013). Introduction to history of Islamic banking in Malaysia. Humanomics, 29(2), 80-87. https://doi.org/10.1108/08288661311319157

Nimako, S. G. (2012). Consumer Switching Behaviour: A Theoretical Review and Research Agenda. Research Journal of Social Science \& Management, 2(3), 74-82.

Otoritas Jasa Keuangan (2017). Press Release: Sharia Finance Gains 8\% Market Share. Retrieved from https://www.ojk.go.id/en/berita-dan-kegiatan/siaran-pers/Pages/Press-Release-Sharia-Finance-Gains8-Market-Share.aspx

Pookulangara, S., Hawley, J., \& Xiao, G. (2011). Explaining consumers' channel-switching behavior using the theory of planned behavior. Journal of Retailing and Consumer Services, 18(4), 311-321. https://doi.org/10.1016/j.jretconser.2011.02.005

Qin, V. Y., \& Xu, A. J. (2016). Attachment to God Reduces Conformity to the Choices of the Majority. Advances in Consumer Research, 44, 269-273. Retrieved from http://www.acrwebsite.org/volumes/v44/acr_vol44_1021932.pdf

Roos, I., Edvardsson, B., \& Gustafsson, A. (2004). Customer Switching Patterns in Competitive and Noncompetitive Service Industries. Journal of Service Research, 6(3), 256-271. https://doi.org/10.1177/1094670503255850

Souiden, N., \& Rani, M. (2015). Consumer attitudes and purchase intentions toward Islamic banks: the influence of religiosity. International Journal of Bank Marketing, 33(2), 143-161. https://doi.org/10.1108/IJBM-10-2013-0115

Sidharta, E. A., Mentari, S. Wafaretta, V., \& Nuraini, U. (2017). Attitude and Perception towards Sharia Insurance Product. International Journal of Business and Commerce, 6(5), 11-23. Retrieved from https://www.ijbcnet.com/6-5/IJBC-17-6502-2.pdf

Suhardih, D. (2018). Kontroversi Halal-Haram Asuransi Syariah. Tahkim: Jurnal Hukum dan Syariah, 14(2), 305-318. https://doi.org/10.33477/thk.v14i2.638

Suryawardani, B., \& Wulandari, A. (2020). Determinant Factors of Customers Switching Behavior to Customer Satisfaction and Loyalty in Online Transportation Users in Bandung. Jurnal Dinamika Manajemen, 11(1), 12-26. https://doi.org/10.15294/jdm.v11i1.21432

Todorof, M. (2018). Shariah-compliant FinTech in the Banking Industry. ERA Forum, 19(1), 1-17. https://doi.org/10.1007/s12027-018-0505-8

Ustaouglu, M. (2014). Public Awareness, Understanding and Attitudes towards Interest-free Insurance (Takaful) Services Evaluation by Education Level: Survey Based on Empirical Analysis for Turkey. Journal of Asian and African Studies, 50(4), 445-456. https://doi.org/10.1177/0021909614533095 
Wahab, A. R. A., Lewis, M. K., \& Hassan, M. K. (2007). Islamic Takaful: Business Models, Shariah Concerns, and Proposed Solutions. Thunderbird International Business Review, 49(3) 371-396. https://doi.org/10.1002/tie.20148

Zhang, X. (2020) The Influences of Brand Awareness on Consumers' Cognitive Process: An Event-Related Potentials Study. Frontiers in Neuroscience. 14:549. https://doi.org/10.3389/fnins.2020.00549 